\title{
Outcrossing in Florida Avocados as Measured Using Microsatellite Markers
}

\author{
James W. Borrone, Cecile T. Olano, David N. Kuhn, J. Steven Brown, and Raymond J. Schnell ${ }^{1}$ \\ United States Department of Agriculture, Agricultural Research Services, Subtropical Horticulture \\ Research Station, National Germplasm Repository, 13601 Old Cutler Road, Miami, FL 33158 \\ Helen A. Violi \\ Department of Plant Pathology, Tropical Research and Education Center, University of Florida, \\ 18905 SW 280th Street, Homestead, FL 33031
}

\begin{abstract}
Additional INDEX words. Persea americana, West Indian, Guatemalan, pollination, progeny, simple sequence repeat, SSR
Abstract. Avocado (Persea americana Mill.) possesses a unique flowering mechanism, thought to promote outcrossing, in which the male and female parts of the perfect flower function at different time periods. Cultivars are classified as Flowering Type A, where flowers are functionally female the morning of one day and functionally male the afternoon of the next day, or Flowering Type B, where flowers are functionally female in the afternoon and functionally male the next morning. Avocado growers typically interplant cultivars of opposite flowering types to maximize yield. Recently, it has been hypothesized that $90 \%$ to $95 \%$ of avocado flowers are self-pollinated in southern Florida. However, this hypothesis does not address whether mature, marketable avocado fruit in Florida are the result of outcrossing. To determine whether avocado fruit in southern Florida result from self-pollination or outcrossing, fruit were harvested from a commercial orchard in Miami-Dade County, Florida, from a block consisting of two cultivars, Simmonds (Flowering Type A) and Tonnage (Flowering Type B), interplanted in approximately equal numbers. Seeds were germinated and the resulting progeny were genotyped using eight fully informative, microsatellite markers. Seventy-four percent of the 'Simmonds' progeny and $96 \%$ of the 'Tonnage' progeny were judged to be the result of cross-pollination, with an estimated overall outcrossing rate of $63 \%$ to $85 \%$ within this particular block of the orchard. Seedlings judged to be the result of cross-pollinations between 'Simmonds' and 'Tonnage' are being maintained at the U.S. Department of Agriculture-Agricultural Research Service, Subtropical Horticulture Research Station and are being evaluated for segregation of important agronomic and horticultural traits.
\end{abstract}

Avocado is an evergreen tree native to Mesoamerica. Persea americana is a polymorphic species consisting of several botanical varieties, or subspecies, adapted to geographically distinct microenvironments. These include wild botanical varieties [var. floccosa Mez, var. steyermarkii Allen, var. nubigena (Williams) Kopp] and three horticulturally important botanical varieties, also known as "races" [var. americana Mill. ("West Indian"), var. guatemalensis Williams ("Guatemalan"), and var. drymifolia (Schlecht. and Cham.) Blake ("Mexican"); Scora and Bergh 1990]. Because of the adaptation to microclimates, hybrids of Guatemalan-Mexican botanical varieties are cultivated in the dry Mediterranean-like environments of California, Israel, Chile, South Africa, and the upland areas of Asia. West Indian or hybrids of West Indian-Guatemalan botanical varieties are cultivated in the more humid tropical environments of Florida, Hawaii, Southeast Asia, and the Caribbean. Mexico is the primary producer of avocados, centered around the state of Michoacán, and 'Hass' is

Received for publication 15 Oct. 2007. Accepted for publication 12 Jan. 2008. We thank Tom Davenport for suggesting the avocado orchard appropriate for this study, and Brooks Tropical for providing the fruit. We also thank Ashley Johnson, Mike Winterstein, Tomas Ayala-Silva, Kathleen Cariaga, and Bryan Grimm for their contributions to various portions of this work.

This work was supported in part by an USDA-CSREES T-STAR grant, "Development of avocado rootstocks via molecular and conventional means." Mention of a trademark, proprietary product, or vendor does not constitute a guarantee or warranty of the product by the U.S. Dept. of Agriculture and does not imply its approval to the exclusion of other products or vendors that also may be suitable.

${ }^{1}$ Corresponding author. E-mail: Ray.Schnell@ars.usda.gov. the most widely grown cultivar worldwide (Ashworth et al., 2007).

Avocado possesses a unique flowering mechanism, called diurnally synchronous protogynous dichogamy, in which the male and female parts of the perfect flower are functional at different time periods (Davenport, 1986; Ish-Am, 2005). Cultivars are classified based upon their flowering behavior as Flowering Type A or Type B (Stout, 1933). Flowering Type A cultivars open in the morning as functional female flowers, close, and then reopen the next day in the afternoon as functional male flowers corresponding to a $36-\mathrm{h}$ cycle. Flowering Type B cultivars first open in the afternoon as functional female flowers, and then the next morning as functional male flowers in a flowering cycle lasting $24 \mathrm{~h}$. Flowering Types A and B compliment one another in that they temporally overlap when one is functionally male and the other is functionally female. This is thought to promote outcrossing between avocado trees of opposite flowering types.

Since the first descriptions of the flowering behavior of avocado (Nirody, 1922; Stout, 1923; Stout and Savage, 1925), the necessity of interplanting cultivars of opposite flowering types to maximize yield has been debated (Davenport, 1986). Early studies and anecdotal reports indicated that interplanting cultivars of opposite flowering types in close proximity increases yield (Bekey, 1986; Gustafson and Bergh, 1966; Robinson, 1933). However, studies using "tented" or "caged" trees with or without pollinators, presumably excluding any pollination events by any external pollen, were equivocal (Clark and Clark, 1926; Degani and Gazit, 1984; Robinson, 1933). A recent report suggests that total exclusion of external pollen 
may have been unrealized unless the tents were diligently maintained (Degani et al., 2003). Furthermore, floral initiation, flowering behavior, and pollen-tube growth are sensitive to microenvironmental conditions, and can be pronounced within individual cultivars (Bringhurst, 1951; Buttrose and Alexander, 1978; Papademetriou, 1976; Robbertse et al., 1995; Robinson, 1933; Salazar-Garcia et al., 1999; Sedgley, 1977; Sedgley and Annells, 1981; Sedgley and Grant, 1983; Sedgley et al., 1985; Stout, 1933; Stout and Savage, 1925). Flowering Type B cultivars are reportedly more sensitive to microenvironmental variations (Peterson, 1956; Sedgley and Grant, 1983).

The application of genetic markers has done little to resolve the debate concerning the interplanting of mixed flowering types. Isozymes developed for avocado (Torres et al., 1978; Torres and Bergh, 1978, 1980) have been used almost exclusively for the identification of potential pollen donors. The majority of studies have been conducted in the Mediterraneanlike climates of California (Kobayashi et al., 2000; VrecenarGadus and Ellstrand, 1985), Israel (Degani et al., 1986, 1989, 1997; Goldring et al., 1987), South Africa (Robbertse et al., 1998), Chile (Gardiazabal and Gandolfo, 1995), and Australia (Sulaiman et al., 2004). Outcrossing has been demonstrated in all studies, but the rate varies according to location, orchard design, developmental stage of the fruit sampled, and the cultivar(s) used as potential pollen donors. An early study in California in commercial 'Hass' orchards using isozymes demonstrated that orchard design affects the level of outcrossing, but described a weak link with overall yield (Vrecenar-Gadus and Ellstrand, 1985). Random amplified polymorphic DNA markers used to investigate outcrossing in commercial 'Hass' orchards in California attributed variations in yield to the effects of location (microclimate) and its interaction with the potential pollen donor rather than to the outcrossing rate observed (Kobayashi et al., 2000). In the abovementioned studies, outcrossing rates were usually inferred because of the limited informativeness of a small number of available molecular markers. The development of three sets of microsatellite markers (Ashworth et al., 2004; Borrone et al., 2007; Sharon et al., 1997) expands the potential number of fully informative markers available. Recently, 10 microsatellites were used to type progeny obtained from a single tree of 'Gwen' in California. Virtually all (203 of the 204 progeny tested) were a result of outcrossing (Ashworth et al., 2007; Chen et al., 2007).

The debate regarding the necessity of interplanting cultivars of opposite flowering types has been reignited by a hypothesis, initially based upon direct observation and manipulation of pollination events, that self-pollination occurs in $90 \%$ to $95 \%$ of the avocado flowers in Florida (Davenport et al., 1994). Originally proposed because of the subtropical environmental conditions prevalent in southern Florida, this hypothesis has since been expanded to the Mediterranean-like climate of California (Davenport et al., 2006). This hypothesis does not address whether mature fruit in Florida are primarily a result of self- (and close-) or cross-pollination events. Only an extremely small percentage of flowers produced by a single avocado tree, less than $0.1 \%$ flowers, ultimately set fruit. The number of fruit reaching maturity is further reduced by fruit drop, and evidence suggests that there is a bias against self- or close-pollinated fruit and that stressful environmental conditions may influence the amount of fruit abortion that occurs (Degani et al., 1986, 1997).

As part of a program to develop increased rootstock tolerance to phytopthora root rot in Florida, 1925 mature fruit were acquired from a block of an orchard in Miami-Dade County, Florida, interplanted with two cultivars of opposite flowering types, Simmonds (Flowering Type A) and Tonnage (Flowering Type B), in about equal numbers. 'Simmonds' and 'Tonnage' avocado are reported as able to self-pollinate (Davenport, 1999; Imbert, 1997). Progeny were genotyped using eight fully informative ('Simmonds' and 'Tonnage' do not share any alleles in common) microsatellite markers. This provides an estimation of the level of outcrossing occurring in Florida within mature, marketable fruit.

\section{Materials and Methods}

Fruit. Avocados were sampled from a commercial orchard (Brooks Tropicals, Homestead, FL). The overall orchard (Block 155; Fig. 1) is 62.7 ha, and is bordered on the north and west by major roads and to the southeast by a railroad track. Mature, flowering trees are planted in three blocks. Fruit were obtained from the north-westernmost block of the orchard (Block 1) consisting of 25 rows $\times 38$ trees of 'Simmonds' (Flowering Type A) and 'Tonnage' (Flowering Type B) interplanted with one another. From west to east, rows one and two are 'Simmonds', rows three and four are 'Tonnage', and this arrangement alternates for a total of 24 rows ending with a single row (row 25) of 'Simmonds' (Fig. 1). A total of 494

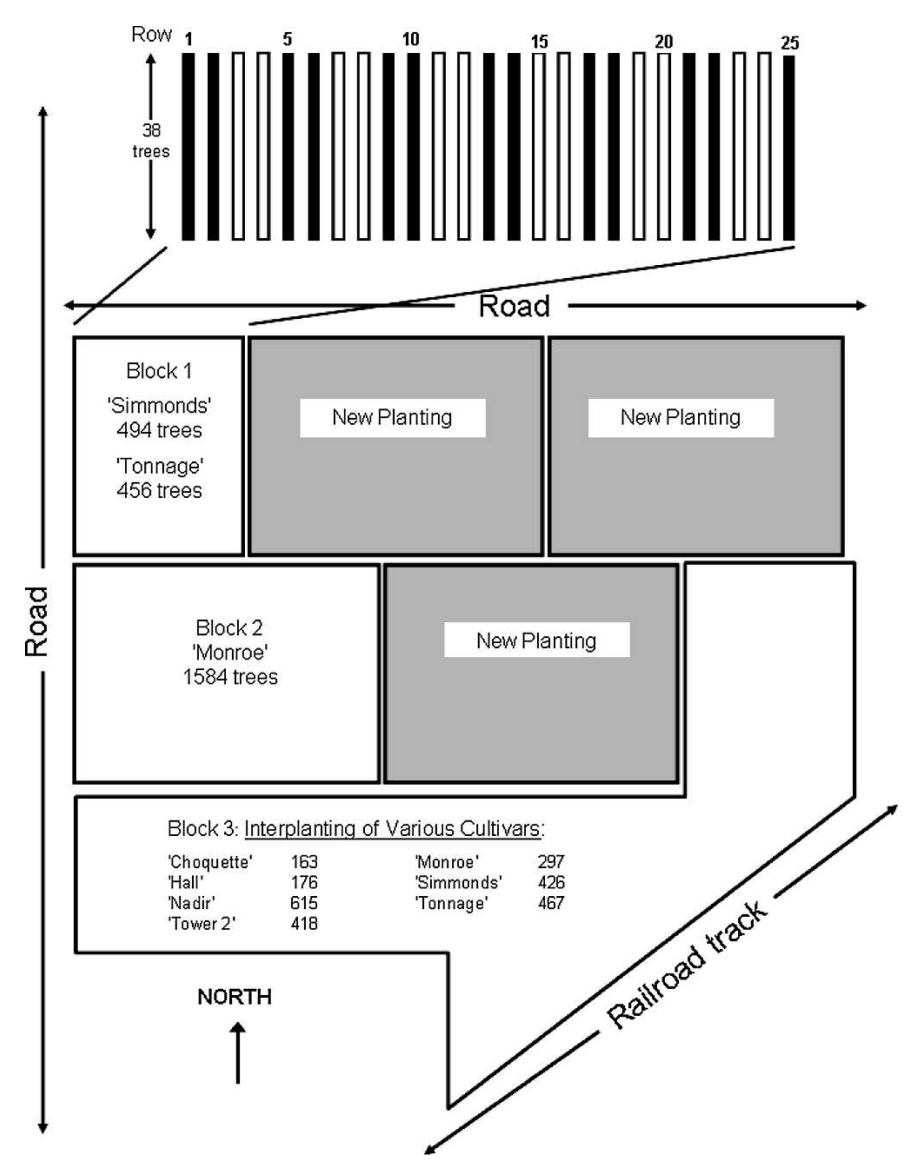

Fig. 1. Organization of the avocado orchard from which 'Simmonds' and 'Tonnage' fruit were harvested. Blocks are drawn roughly to scale. All of the 'Simmonds' and 'Tonnage' fruit were harvested from Block 1. Rows containing 'Simmonds' trees are shown in black, rows containing 'Tonnage' trees are shown in white. 
'Simmonds' trees and 456 'Tonnage' trees are interplanted in Block 1. Trees within each row are spaced $6.1 \mathrm{~m}$ apart from one another, and the rows are separated by $7.6 \mathrm{~m}$. Both cultivars were maintained at $\approx 8 \mathrm{~m}$ in height with interleaved branches interspersed across rows. To the immediate east and southeast of Block 1 are newly planted fields. To the immediate south of the 'Simmonds' and 'Tonnage' interplanting is a block (Block 2) consisting of 1584 'Monroe' trees. The southern-most block (Block 3) consists of 'Simmonds' (426 trees), 'Tonnage' (467), 'Tower 2' (418), 'Choquette' (163), 'Hall' (176), 'Nadir' (615), and 'Monroe' (297) randomly interplanted with one another. Fruit harvested by the grower from 'Simmonds' were received during the first week of Aug. 2006, and fruit harvested by the grower from 'Tonnage' were received the first week of Sept. 2006.

Climate conditions during the flowering period of 'Simmonds' and 'Tonnage' in 2006 (University of Florida et al., 2007) and the historical monthly averages from 1971 through 2001 (Southeast Regional Climate Center, 2007) for Homestead, Florida, are presented in Table 1. All measurements were made $2 \mathrm{~m}$ from the ground at the Homestead Experiment Station, no. 084901 , located $6.7 \mathrm{~km}$ south of the orchard at the University of Florida, Tropical Research and Education Center (lat. $25^{\circ} 30^{\prime} \mathrm{N}$ long. $80^{\circ} 30^{\prime} \mathrm{W}$ ).

Germination. Fruit were kept at room temperature in the original boxes in which they had been packaged, or removed and placed within paper bags, until ripe. Seeds were removed from the ripened fruit, and planted immediately ('Simmonds') or allowed to "dry" for up to 1 week and then planted ("Tonnage'). Before planting, the seedcoats were removed from all seeds except for 150 seeds obtained from overripened 'Simmonds' fruit. A total of 869 'Simmonds' and 1057 'Tonnage' seeds were planted. The seeds were allowed to germinate over 3 months in separate greenhouses. After planting, the pots were treated one time with a copper-based fungicide. Germinated seedlings were treated one time with a mixture of abamectin and imidacloprid. Pots were watered by hand as needed (up to twice per day) to keep the medium moist. After 3 months, seeds that either had not germinated or had "germinated" but produced only roots (no shoots) were discarded.

SubSTRATE. Seeds were germinated in 3.8-L plastic pots, lined with paper towels, in vermiculite. After the first whorl of true leaves had formed, the seedlings were repotted (in the same pots) into a soilless medium (Nursery Mix; Atlas Peat \& Soil, Boynton Beach, FL) consisting of $50 \%$ pine bark, $10 \%$ sand, $40 \%$ coir dust, $4.5 \mathrm{~kg} \cdot \mathrm{m}^{-1}$ of dolomite, and $1.5 \mathrm{~kg} \cdot \mathrm{m}^{-1}$ micromax, and were fertilized ( $9 \mathrm{~g}$ per pot of Nutricote Total Type 180, 18N-2.6P-6.6K; Florikan E.S.A. Corp., Sarasota, FL). Before repotting, the soilless medium was steamed for 6 to $7 \mathrm{~h}$ until a temperature of $82{ }^{\circ} \mathrm{C}$ was reached, as determined with a compost thermometer, to reduce any potential fungal contaminates. The medium was allowed to cool overnight, and was then steamed a minimum of $2 \mathrm{~h}$ the next day, and allowed to cool overnight again.

SAMPling. DNA was isolated using the FastDNA SPIN Kit (MP Biomedical, Solon, $\mathrm{OH}$ ) as described in Schnell et al. (2003) from young, fully expanded, green leaves collected from the seedlings. For seedlings that had multiple stems, the individual stems were tagged, and DNA was isolated separately from leaves collected from each stem. Leaves were also collected randomly from 'Tonnage' and 'Simmonds' trees in Block 1 from which the fruit were harvested.

Screening of Progeny. The progeny were screened with eight microsatellites (Table 2). Six microsatellites (Lavi et al., 1994; Sharon et al., 1997) have been used previously to characterize the avocado germplasm collection maintained at the U.S. Department of Agriculture (USDA)-Agricultural Research Service (ARS), Subtropical Horticulture Research Station (SHRS), Miami, Florida (Schnell et al., 2003). Two others, SHRSPa010 and SHRSPa055 (Borrone et al., 2007), were recently developed by data-mining $P$. americana expressed sequence tag sequences developed as part of the Floral Genome Project (Albert et al., 2005). These loci were selected specifically because 'Simmonds' and 'Tonnage' do not share alleles in common (Table 2).

All polymerase chain reactions (PCRs) were prepared with a MultiPROBE II PLUS HT EX Robot Liquid Handling System (PerkinElmer, Life Sciences, Dowers Grove, IL) and conducted with PTC-225 thermal cyclers (MJ Research, Waltham, MA) in 96-well plates. Each PCR contained $0.1 \mu \mathrm{M}$ forward primer, $0.1 \mu \mathrm{M}$ reverse primer, $200 \mu \mathrm{M}$ dNTPs, $10 \mathrm{ng}$ of bovine serum albumin, $1 \times$ PCR buffer $(10 \mathrm{~mm}$ Tris- $\mathrm{HCl}, 50 \mathrm{~mm} \mathrm{KCl}$, and 1.5 $\mathrm{mm} \mathrm{MgCl}_{2}, \mathrm{pH} 8.3$, at $25^{\circ} \mathrm{C}$ ), $0.5 \mathrm{U}$ of NEB polymerase (New England Biolabs, Ipswich, MA), and $1 \mu \mathrm{L}$ of a 1:20 dilution $(\approx 5-20 \mathrm{ng})$ of DNA in a total volume of $10 \mu \mathrm{L}$. Thermal cycler conditions were: $94{ }^{\circ} \mathrm{C}$ for $2 \mathrm{~min}\left[94{ }^{\circ} \mathrm{C}\right.$ for $20 \mathrm{~s}$; annealing temperature $\left.\left(\mathrm{T}_{\mathrm{A}}\right){ }^{\circ} \mathrm{C}, 45 \mathrm{~s} ; 72{ }^{\circ} \mathrm{C}, 1 \mathrm{~min}\right] \times 35$ or 40 cycles; $72{ }^{\circ} \mathrm{C}$ for $10 \mathrm{~min}$, and held indefinitely at $4{ }^{\circ} \mathrm{C}$ (see Table 2 for $\mathrm{T}_{\mathrm{A}}$ ). Post-PCR, samples were diluted up to $20 \mu \mathrm{L}$ with sterile $\mathrm{H}_{2} \mathrm{O}$, ethanol-precipitated, and resuspended in $20 \mu \mathrm{L}$ of $\mathrm{H}_{2} \mathrm{O}$. One microliter of the PCR product was added to $19.9 \mu \mathrm{L}$ of $\mathrm{H}_{2} \mathrm{O}$ and $0.1 \mu \mathrm{L}$ of ROX-labeled GeneScan-400HD molecular size standard (Applied Biosystems, Foster City, CA), denatured at $95{ }^{\circ} \mathrm{C}$ for $1 \mathrm{~min}$, and chilled on ice. Capillary electrophoresis was performed on the ABI Prism 3730 Genetic Analyzer using Performance Optimized Polymer 7 (POP 7; Applied Biosystems), and analyzed using GeneMapper version 4.0 (Applied Biosystems). Analysis of the potential pollen donor was

Table 1. Monthly mean values for air temperature and relative humidity and total measured precipitation from Jan. through Apr. 2006, the flowering period of 'Simmonds' and 'Tonnage' avocado in southern Florida compared with mean monthly temperatures and precipitation from 1971 through 2001, given in parentheses, for Homestead, Florida.

\begin{tabular}{|c|c|c|c|c|c|c|c|}
\hline \multirow[b]{2}{*}{ Month } & \multicolumn{3}{|c|}{ Avg air temp $\left({ }^{\circ} \mathrm{C}\right)$} & \multicolumn{2}{|c|}{ Absolute air temp ${ }^{z}\left({ }^{\circ} \mathrm{C}\right)$} & \multirow{2}{*}{$\begin{array}{l}\text { Precipitation } \\
(\mathrm{mm})\end{array}$} & \multirow{2}{*}{$\begin{array}{l}\text { Avg relative } \\
\text { humidity (\%) }\end{array}$} \\
\hline & Daily & Maximum & Minimum & Maximum & Minimum & & \\
\hline January & $19.0(19.0)$ & $24.2(24.8)$ & $13.3(13.2)$ & 27.9 & 3.2 & $14.0(49.3)$ & 77 \\
\hline February & $17.9(19.4)$ & $24.1(25.2)$ & $11.7(13.7)$ & 30.5 & 3.2 & $88.1(45.2)$ & 77 \\
\hline April & $23.0(22.9)$ & $28.7(28.7)$ & $17.0(17.1)$ & 31.8 & 12.5 & $69.9(69.6)$ & 72 \\
\hline
\end{tabular}

The absolute maximum and minimum reading obtained during the month during any 15 -min interval. 
performed manually. Progeny were determined as potentially the result of self-pollination if only maternal alleles were found at all scorable loci, and potentially the result of an outcross if one or more loci had an allele other than those found in the maternal parent. The results determined manually were verified using CERVUS, version 3.0 (Marshall et al., 1998; Slate et al., 2000).

\section{Results and Discussion}

The germination rate (Table 3) differed between the 'Tonnage' and 'Simmonds' seeds and may reflect differences in the environmental conditions of the separate greenhouses, treatment the seeds received before planting, or the developmental stage of the individual embryos (Perán-Quesada et al., 2005). A small number $(<40)$ of the 'Simmonds' seeds initiated germination, but only produced roots, and had not produced shoots, by the arbitrarily determined 3-month cutoff. This lack of full germination was not observed in any of the 'Tonnage' progeny. A single 'Simmonds' and three 'Tonnage' seedlings had the opposite developmental phenotype where the seedling produced a single shoot with fully expanded leaves, but had not developed roots at the time of repotting. After repotting, these "rootless" progeny developed apparently healthy, normal-looking root systems. These developmental phenotypes, roots or shoots only, are similar to those described for in vitro germination of immature avocado zygotic 'Hass' embryos (Perán-Quesada et al., 2005). Few other phenotypic differences were noted in the seedlings, the only other obvious phenotype was a single variegated 'Simmonds' seedling.

Five of the eight microsatellite loci amplified well across all samples. Three of the loci investigated, AVAG06, AVAC01, and SHRSPa055, were inconsistent in amplification and suffered from an excess of "allele dropout." In all cases, the affected allele was the larger of the two alleles present in 'Tonnage' (Table 2). Inconsistent amplification, the detection of "null" alleles, among avocado accessions has been previously noted in microsatellite markers developed for avocado (Ashworth et al., 2004; Borrone et al., 2007; Sharon et al., 1997). Post-PCR treatment with ethanol or, in a subset of samples, exonuclease (data not shown) for these three loci did not improve the electropherograms, suggesting that the results obtained were because of selective amplification, not preferential electrokinetic injection, of the smaller-sized alleles during electrophoresis. This was verified by reamplification of a subset of samples with SHRSPa055 in which the "missing" allele was "recovered" (data not shown). Therefore, AVAG06, AVAC01, and SHRSPa055 were loci (three seedlings). only partially informative for determining outcrossing. Overall, the average amount of missing data were low, only $1.3(\mathrm{SD}=$ 0.93 ) loci/sample. One sample failed to amplify across a majority of the loci, and three progeny possessed alleles at one or more loci other than those of the presumed maternal parent. These were excluded from further analysis (Table 3). Samples collected randomly from 'Tonnage' and 'Simmonds' trees interplanted in Block 1 of the orchard were genetically identical with the 'Tonnage' and 'Simmonds' accessions maintained in the

Table 2. Eight microsatellite loci used for estimating outcrossing in progeny of 'Simmonds' and 'Tonnage' avocado. Microsatellite loci that are partially informative because of poor amplification or they are suffering from an excess of allele "dropout," and the particular allele affected is italicized.

\begin{tabular}{llccr}
\hline Microsatellite & \multicolumn{2}{c}{ Source } & $\mathrm{T}_{\mathrm{A}}^{\mathrm{z}}\left({ }^{\circ} \mathrm{C}\right)$ & \multicolumn{2}{c}{ Genotype $^{\mathrm{y}}$ (no. of nucleotides) } \\
\cline { 5 - 5 } locus & 'Simmonds' & 'Tonnage' \\
\hline AVAG05 & Sharon et al., 1997 & 50 & 94 & 91,106 \\
AVAG03 & Sharon et al., 1997 & 45 & 103 & 99,105 \\
AVMIX03 & Sharon et al., 1997 & 45 & 143,153 & 145,160 \\
AVAG22 & Sharon et al., 1997 & 55 & 103,116 & 105,127 \\
AVAG06 & Sharon et al., 1997 & 40 & 72 & 66,85 \\
AVAC01 & Sharon et al., 1997 & 40 & 108 & 117,122 \\
SHRSPa010 & Borrone et al., 2007 & 60 & 142 & 136 \\
SHRSPa055 & Borrone et al., 2007 & 55 & 102,116 & 108,133 \\
\hline
\end{tabular}

${ }^{\mathrm{z}} T_{A}$, annealing temperature.

${ }^{\mathrm{y}} \mathrm{A}$ single number is given for the genotype at the microsatellite loci where the individual is homozygous for the same-sized alleles.

Table 3. Germination results of seed collected from 'Tonnage' and 'Simmonds' avocado fruit, and the number of progeny that resulted from outcrossing or self-pollination as determined by genotyping with eight microsatellite loci.

\begin{tabular}{lccc}
\hline Maternal parent & 'Tonnage' & 'Simmonds' & Total \\
\hline Seeds (no.) & & & \\
$\quad$ Planted & 1057 & 869 & 1926 \\
$\quad$ Nongerminated & 356 & 136 & 492 \\
$\quad$ Germinated (\%) & $701(66.3)$ & $733(84.3)$ & $1434(75.3)$ \\
Progeny (no.) & & & \\
Not assayed & 1 & 4 & 5 \\
Assayed & 700 & 729 & 1429 \\
Excluded & 1 & 3 & 4 \\
Total assayed & 699 & 726 & 1425 \\
Outcrosses (no.) & & $536(73.8)$ & $711(49.9)$ \\
Observed (\%) & $672(96.1)$ & $348(48)$ & 364.6 \\
Expected (\%) & $363(52)$ & 101.6 & \\
$\chi^{2 \mathrm{v}}$ & 263.0 & & $217(15.2)$ \\
Selfs (no.) & & $190(26.2)$ & $714(50.1)$ \\
Observed $(\%)^{\mathrm{y}}$ & $27(3.9)$ & $378(52)$ & 377.7 \\
$\chi^{2 \mathrm{v}}$ & $336(48)$ & 93.5 &
\end{tabular}

${ }^{\mathrm{z}}$ As determined 3 months after planting. Seeds that only produced roots and did not produce shoots were included in this category.

y Progeny were not assayed because they had germinated and died before sampling, or they did not have any leaves at the time of sampling.

xProgeny were excluded from the analysis because of poor amplification across all loci tested (one seedling), or because they did not possess any maternal alleles at one or more

wExpected and percentage expected outcross and self-pollinations were calculated assuming that each individual tree in Block 1 had an equal probability of pollinating any other individual tree in Block 1, including itself. Block 1 contained 494 'Simmonds' trees and 456 'Tonnage' trees.

vdf $=1 ; \mathrm{F}=10.83, P=<0.001$. 
germplasm collection (USDA-ARS, SHRS National Germplasm Repository, Miami, FL).

The incidence of multiple-stems was similar among the progeny obtained from each cultivar, 61 (8.7\%) of the 'Simmonds' and $73(9.9 \%)$ of the 'Tonnage'. Although rare, multiple embryos have been described in avocado and are usually associated with the presence of three or more cotyledons. Multiple stems in avocado usually arise from early branching occurring at the cotyledonary node (Schroeder, 1944). All seedlings with multiple stems had only two cotyledons, and in all but one instance, multiple stems from an individual seed were genetically identical with one another. The single difference noted could not be verified as the smaller, adventitious shoot had not survived when an attempt was made to resample. There was no obvious relation between the occurrence of multiple stems and parentage of the progeny (self vs. outcross).

A significant number of the progeny, 1208 of the 1425 assayed, were judged to be the result of outcrossing, and the estimated level of outcrossing within Block 1 of the orchard is $84.8 \%$ (Table 3 ). This is consistent with outcrossing rates reported in both Chile and California for 'Hass' orchards designed in a similar manner (Gardiazabal and Gandolfo, 1995; Vrecenar-Gadus and Ellstrand, 1985). This does not account for seeds that failed to germinate. It is possible that germination failure could be attributable to some unknown mechanism potentially associated with inbreeding. This is unlikely as the greater percentage of seeds that failed to germinate were from 'Tonnage', a Guatemalan-West Indian hybrid that is highly heterozygous $(>85 \%)$, whereas 'Simmonds' is $35 \%$ heterozygous, as estimated from microsatellite data. A number of the 'Simmonds' seeds that failed to germinate at all were from the 150 seeds in which the seedcoat was left on (data not shown), a factor known to inhibit seed germination in avocados (Bergh, 1988; Eggers, 1942; Whiley and Whiley, 2005). Even if seeds that failed to germinate are included as selfs, the overall outcrossing rate measured in Block 1 of the orchard is $63 \%\left(\chi^{2}=44.8, \mathrm{df}=1, \mathrm{~F}=10.83, P=<0.001\right)$. If $90 \%$ to $95 \%$ of flowers in Florida are the result of selfpollinations as has been hypothesized, then significant differences in successful fertilizations of the ovary or the degree of flower and fruitlet abscission, biased against selfed or closepollinated fruit, are potential mechanisms explaining the high number of outcrossed individuals detected in mature, marketable fruit. It has been demonstrated that successful penetration of the ovary by pollen is time and temperature dependent, and varies among pollen donors (Robbertse et al., 1995; Sedgley, 1977; Sedgley and Grant, 1983). Selective abscission of highly homozygous, immature fruitlets has been observed in Israel (Degani et al., 1986, 1997). 'Simmonds' and 'Tonnage' exhibit the two different mechanisms, Type 1 and Type 2, affecting avocado fruit set. 'Simmonds' initially sets a large crop with subsequent fruit drop (Type 1), whereas 'Tonnage' (Type 2) typically has a smaller initial fruit set with very little drop (Davenport, 1982; M. Bass, pers. comm.). Climatic conditions during the flowering period of 'Simmonds' and 'Tonnage' avocado in 2006 were comparable with the means obtained over a thirty year period, 1971 through 2001, for Homestead, Florida (Table 1). The monthly maximum and minimum mean daily temperatures were similar to the optimal maximum/ minimum temperatures reported for flowering and pollen tube growth (Robbertse et al., 1995; Sedgley, 1977; Sedgley and Grant, 1983).
There was a significant difference in the "identity" of the potential pollen donor between the two cultivars. For the 'Tonnage' progeny, 'Simmonds' was determined as the potential pollen donor for 592 of the $672(88.1 \%)$ outcrossed individuals; only 80 'Tonnage' progeny were outcrosses with an "unknown" pollen donor. For the "Simmonds', 74\% of the progeny were outcrossed; however, the outcrossed seedlings were equally divided between those potentially pollinated by 'Tonnage' (278) and those pollinated by another, undetermined donor (258). In Florida, 'Simmonds' initiates flowering slightly earlier than 'Tonnage' (M. Bass, personal communication). The difference noted between the two cultivars of the potential pollen donors is likely because of this difference in flowering period.

An attempt was made to determine the potential identity of these "unknown" pollen donors. Data over 14 microsatellite markers had previously been collected from representative accessions maintained at the USDA-ARS, National Germplasm Repository in Miami, Florida (Schnell et al., 2003) for three of the five other cultivars (Monroe, Choquette, and Tower 2) present within other regions of the orchard (Fig. 1). The genotypes of 'Hall' and 'Nadir' are unknown. 'Choquette', 'Tower 2', 'Monroe', and 'Simmonds' were found to be genetically similar with one another for six of the eight loci used in this study (Table 4). For example, between 'Tower 2' and 'Simmonds', only two loci are partially informative (they share an allele in common) out of the 14 loci for which they have been genotyped (Schnell et al., 2003). Thus, it is possible that the number of selfed 'Simmonds' progeny is overestimated.

Immediately south of the 'Simmonds' and 'Tonnage' interplanting is a solid block of 'Monroe' (Block 2, Fig. 1). In Florida, the flowering period of 'Monroe' overlaps very little with 'Simmonds' or 'Tonnage' (Davenport, 1982; M. Bass, pers. comm.). None of the outcrossed 'Tonnage' progeny of unknown pollen donor could be identified as originating from 'Monroe', and only eight (10\%) of the outcrossed progeny of "unknown" parentage from 'Tonnage' could be assigned with any degree of certainty to 'Choquette' (data not shown). Interestingly, if any outcrossing occurred among the cultivars reportedly within the commercial orchard sampled, then pollen was dispersed over a minimum of $>300 \mathrm{~m}$ (as estimated from satellite photos; Google-Imagery et al., 2007). Another potential source of the "unknown" pollen donors is an avocado orchard of unknown composition to the west (across the major road) of the sampled 'Simmonds' and 'Tonnage' block $(\approx 100-$ $150 \mathrm{~m}$ away). Similar difficulty has been described in trying to determine the potential pollen donors for open-pollinated progeny obtained from a single 'Gwen' tree in California (Ashworth et al., 2007; Chen et al., 2007).

The genetic similarity noted among the potential pollen donors is not a trivial matter for breeding purposes, classification of cultivars by horticultural race, or determining the "evolutionary" relationships of cultivated versus wild Persea species using molecular markers. The degree of relatedness of avocado cultivars is generally unknown, as selection has historically been made from open-pollinated seedlings. This, as well as other results obtained in our laboratory $(\mathrm{H}$. Violi, personal communication), suggest that commercially important Florida cultivars originate from a narrow genetic base, similar to what has been described for Florida cultivars of mango (Mangifera indica L.; Schnell et al., 2006). The 870 progeny originally judged as outcrosses between 'Simmonds' and 
Table 4. Genotypes of three other avocado cultivars that could be potential pollen donors compared with the genotypes of 'Simmonds' and 'Tonnage' avocado for six of the eight microsatellite loci used in this study.

\begin{tabular}{|c|c|c|c|c|c|c|c|c|c|}
\hline \multirow{2}{*}{$\begin{array}{l}\text { Avocado } \\
\text { cultivar }\end{array}$} & \multirow{2}{*}{$\begin{array}{l}\text { Horticultural } \\
\text { race }^{z}\end{array}$} & \multirow{2}{*}{$\begin{array}{c}\text { Flowering } \\
\text { type }\end{array}$} & \multirow{2}{*}{$\begin{array}{l}\text { Maternal } \\
\text { parent }^{\mathrm{y}}\end{array}$} & \multicolumn{6}{|c|}{ Microsatellite $\operatorname{loci}^{\mathrm{x}}$ (no. nucleotides) } \\
\hline & & & & AVAG05 & AVAG03 & AVMIX03 & AVAG22 & AVAG06 & AVAC01 \\
\hline Tonnage & $\mathrm{G} \times \mathrm{W}$ & $\mathrm{B}$ & 'Taylor' & 91,105 & 98,104 & 143,160 & 104,124 & 65,83 & 115,119 \\
\hline Simmonds & $\mathrm{W}$ & A & 'Pollock' & 93 & 102 & 141,152 & 102,114 & 71 & 107 \\
\hline Monroe & $\mathrm{G} \times \mathrm{W}$ & B & 'Waldin'? & 93 & 102 & 141,151 & 104,124 & 65 & 107 \\
\hline Tower 2 & $\mathrm{~W}$ & B & ‘Waldin’ & 93 & 102 & 141,152 & 102,104 & 65,71 & 107 \\
\hline
\end{tabular}

${ }^{\mathrm{z}}$ Horticultural race as determined in Schnell et al. (2003). $\mathrm{W}=$ West Indian, $\mathrm{G} \times \mathrm{W}=$ Guatemalan/West Indian hybrid.

${ }^{y}$ Maternal parent, as reported in the literature. All cultivars are open pollinated seedlings. The parents of 'Choquette', and the actual maternal parent for 'Monroe' are not known. 'Monroe' was originally discovered in 1935 as a seedling growing underneath a 'Waldin' tree; other possible parents include 'Schmidt', 'Taft', or 'Eagle Rock' (syn. 'Galloupe').

${ }^{x}$ Alleles of the other potential pollen donors that are shared with 'Simmonds' or 'Tonnage' are given in bold. Alleles shared only among the other potential pollen donors are italicized. A single number is given for the genotype at microsatellite loci where the individual is homozygous for the same-sized alleles. The genotypes of two other potential pollen donors, 'Hall' and 'Nadir', are not known. Molecular sizes of the alleles differ from those reported in Table 2 because of differences in the electrophoresis conditions and the internal molecular weight size standard used in this study and in Schnell et al., (2003).

'Tonnage' have been assayed with 60 additional microsatellite primers (data not shown). Based upon mismatches at more than one locus, 14 of these individuals have been further identified as "off-types" (the potential pollen parent is not 'Simmonds' or 'Tonnage'). Twelve of the 14 “off-types" have 'Tonnage' as the maternal parent.

In summary, 1425 seedlings obtained from 'Simmonds' or 'Tonnage' interplanted with one another within a block of an avocado orchard in southern Florida were assayed with eight microsatellite markers. The overall level of outcrossing detected was $85 \%$, significantly higher than the $50 \%$ expected by chance alone. The level of outcrossing detected for each cultivar, $96 \%$ for 'Tonnage' versus $74 \%$ for 'Simmonds', and the identity of the potential pollen donor varied. Because of the genetic similarity of 'Simmonds' with other potential pollen donors, the level of outcrossing for 'Simmonds' may have been underestimated. The results of this study are limited to a single year and a single block of an avocado orchard, but demonstrate that under certain conditions, high levels of outcrossing can occur in southern Florida. If indeed $90 \%$ to $95 \%$ of avocado flowers are self-pollinated in southern Florida, then variations in pollen tube growth or genetically based selective flower and fruit abscission may explain the high levels of outcrossing observed in progeny obtained from mature, marketable fruit. What effect, if any, outcrossing rate has on overall fruit yield in southern Florida remains to be determined. Seedlings judged to be the result of cross-pollinations between 'Simmonds' and 'Tonnage' are being maintained at the USDA-ARS, SHRS, and are being evaluated for segregation of important agronomic and horticultural traits.

\section{Literature Cited}

Albert, V.A., D.E. Soltis, J.E. Carlson, W.G. Farmerie, P.K. Wall, D.C. Ilut, T.M. Solow, L.A. Mueller, L.L. Landherr, Y. Hu, M. Buzgo, S. Kim, M.-J. Yoo, M.W. Frohlich, R. Perl-Treves, S.E. Schlarbaum, B.J. Bliss, X. Zhang, S.D. Tanksley, D.G. Oppenheimer, P.S. Soltis, H. Ma, C.W. dePamphilis, and J.H. Leebens-Mack. 2005. Floral gene resources from basal angiosperms for comparative genomics research. BMC Plant Biol. 5:5. doi:10.1186/1471-2229-5-5. 13 Nov. 2007. $<\mathrm{http}$ ://www.biomedcentral.com/content/pdf/1471-2229-5-5.pdf $>$.

Ashworth, V.E.T.M., H. Chen, and M.T. Clegg. 2007. 17 Avocado, p. 325-329. In: C. Kole (ed.). Genome mapping and molecular breeding in plants, Volume 4, Fruits and nuts. Springer-Verlag Berlin-Heidelberg, Germany.

Ashworth, V.E.T.M., M.C. Kobayashi, M. De La Cruz, and M.T. Clegg. 2004. Microsatellite markers in avocado (Persea americana Mill.): Development of dinucleotide and trinucleotide markers. Scientia Hort. 101:255-267.

Bekey, R. 1986. Pollination of avocado: Some new insights with special reference to the 'Hass' variety. California Avocado Soc. Yrbk. 70:91-98.

Bergh, B. 1988. The effect of pretreatments on avocado seed germination. California Avocado Soc. Yrbk. 72:215-221.

Borrone, J.W., R.J. Schnell, H.A. Violi, and R.C. Ploetz. 2007. Seventy microsatellite markers from Persea americana Miller (avocado) expressed sequence tags. Mol. Ecol. Notes 7(3):439444.

Bringhurst, R.S. 1951. Influence of glasshouse conditions on flower behavior of Hass and Anaheim avocados. California Avocado Soc. Yrbk. 36:164-168.

Buttrose, M.S. and D.McE. Alexander. 1978. Promotion of floral initiation in 'Fuerte' avocado by low temperature and short daylength. [sic]. Scientia Hort. 8:213-217.

Chen, H., V.E.T.M. Ashworth, S. Xu, and M.T. Clegg. 2007. Quantitative analysis of growth rate in avocado. J. Amer. Soc. Hort. Sci. 132(5):691-696.

Clark, O.I. and A.B. Clark. 1926. Results of pollination and other experiments on avocados at orchards of the Point Loma Homestead. California Avocado Assn. Annu. Rpt. 1925-26.11:85-94.

Davenport, T.L. 1982. Avocado growth and development. Proc. Florida State Hort. Soc. 95:92-99.

Davenport, T.L. 1986. Avocado flowering. Hort. Rev. (Amer. Soc. Hort. Sci.) 8:257-289.

Davenport, T.L. 1999. A view from Florida on avocado pollination, p. 101-104. In: M.L. Arpaia and R. Hofshi (eds.). Proceedings of the Avocado Brainstorming. Session 5. Pollination. Riverside, CA. 2728 Oct. 1999. Hofshi Foundation.

Davenport, T.L., P. Parnitzki, S. Fricke, and M.S. Hughes. 1994. Evidence and significance of self-pollination of avocados in Florida. J. Amer. Soc. Hort. Sci. 119:1200-1207.

Davenport, T.L., Z. Ying, and R.J. Schnell. 2006. Use of simple sequence repeats (SSR) to determine incidence and effectiveness of self- and cross-pollinated avocado fruit in southern California, Year 3 of 3. Proc. California Avocado Res. Symp. Univ. of California, Riverside. 4 Nov. 2006. p. 64-80.

Degani, C., R. El-Batsri, and S. Gazit. 1997. Outcrossing rate, yield, and selective fruit abscission in 'Ettinger' and 'Ardith' avocado plots. J. Amer. Soc. Hort. Sci. 122(6):813-817. 
Degani, C. and S. Gazit. 1984. Selfed and crossed proportions of avocado progenies produced by caged pairs of complimentary cultivars. HortScience 19(2):258-290.

Degani, C., A. Goldring, and S. Gazit. 1989. Pollen parent effect on outcrossing rate in 'Hass' and 'Fuerte' avocado plot during fruit development. J. Amer. Soc. Hort. Sci. 114:106-111.

Degani, C., A. Goldring, S. Gazit, and U. Lavi. 1986. Genetic selection during the abscission of avocado fruitlets. HortScience 21(5):11871188.

Degani, C., E. Lahav, R. El-Batsri, and S. Gazit. 2003. Caging single avocado trees with a beehive does not guarantee exclusive formation of selfed progeny. HortScience 38(7):1433-1434.

Eggers, E.R. 1942. Effect of the removal of the seed coats on avocado seed germination. California Avocado Soc. Yrbk. 27:41-43.

Gardiazabal, F.J. and S. Gandolfo. 1995. A study of self-pollination and cross-pollination in avocado (Persea americana Mill.) cv. Hass of different varieties. Proc. World Avocado Congr. III. p. 52-56.

Goldring, A., G. Gazit, and C. Degani. 1987. Isozyme analysis of mature avocado embryos to determine outcrossing rate in a 'Hass' plot. J. Amer. Soc. Hort. Sci. 112(2):389-392.

Google-Imagery. DigitalGlobe, and Florida Department of Environmental Protection. 2007. Satellite compilation photo of "Block 155" avocado orchard, Miami-Dade County, Fla. 20 Oct. 2007. <http:// maps.google.com $/ \mathrm{maps} / \mathrm{mm}$ ? ie=UTF $8 \& \mathrm{hl}=$ en $\& 1 \mathrm{l}=25.561258$,$80.47554 \& \mathrm{spn}=0.008633,0.014462 \& \mathrm{t}=\mathrm{k} \& \mathrm{z}=16 \& \mathrm{om}=0>$.

Gustafson, C.D. and B.O. Bergh. 1966. History and review of studies on cross-pollinations of avocados. California Avocado Soc. Yrbk. 50:39-49.

Imbert, F.M. 1997. Delayed pistil senescence causes an overlap in protogyny in 'Tonnage' avocado (Persea americana Mill.). California Avocado Soc. Yrbk. 81:99-106.

Ish-Am, G. 2005. Avocado pollination: A review. New Zealand and Australia Growers' Conf. '05. Session 7. Flowering, fruit set, and yield.

Kobayashi, M., J.-Z. Lin, J. Davis, L. Francis, and M.T. Clegg. 2000. Quantitative analysis of avocado outcrossing and yield in California using RAPD markers. Scientia Hort. 86:135-149.

Lavi, U., M. Akkaya, A. Bhagwat, E. Lahav, and P.B. Cregan. 1994. Methodology of generation and characteristics of simple sequence repeat DNA markers in avocado (Persea americana M.). Euphytica 80:171-177.

Marshall, T.C., J. Slate, L. Kruuk, and J.M. Pemberton. 1998. Statistical confidence for likelihood-based paternity inference in natural populations. Mol. Ecol. 7:639-655.

Nirody, B.S. 1922. Investigations in avocado breeding. California Avocado Assn. Annu. Rpt. 1921-1922. 7:65-78.

Papademetriou, P. 1976. Some aspects of the flower behavior, pollination, and fruit set of avocado (Persea americana Mill.) in Trinidad. California Avocado Soc. Yrbk. 60:106-152.

Perán-Quesada, R., C. Sánchez-Romero, F. Pliego-Alfaro, and A. Barceló-Muñoz. 2005. Histological aspects of avocado embryo development and effect of developmental stages on germination. Seed Sci. Res. 15:125-132.

Peterson, P.A. 1956. Flowering types in the avocado with relation to fruit production. California Avocado Soc. Yrbk. 40:174-179.

Robbertse, P.J., L.A. Coetzer, M.F. Smith, and W. Conradie. 1995. Effect of pollen parent on pollen tube growth in Hass avocados. South African Avocado Grower's Assn. Yrbk. 18:17-19.

Robbertse, P.J., M.F. Johannsmeier, and T.M. Morudu. 1998. Pollination of Hass avocados. South African Avocado Grower's Assn. Yrbk. 21:63-68.

Robinson, T.R. 1933. Pollination and other factors influencing the production of avocados. Proc. Florida State Hort. Soc. 46:109-114. Salazar-García, S., E.M. Lord, and C.J. Lovatt. 1999. Inflorescence development of the 'Hass' avocado: Commitment to flowering. J. Amer. Soc. Hort. Sci. 124(5):478-482.
Schnell, R.J., J.S. Brown, C.T. Olano, E.J. Power, C.A. Krol, D.N. Kuhn, and J.C. Motamayor. 2003. Evaluation of avocado germplasm using microsatellite markers. J. Amer. Soc. Hort. Sci. 128(6):881889.

Schnell, R.J., J.S. Brown, C.T. Olano, A.W. Meerow, R.J. Campbell, and D.N. Kuhn. 2006. Mango genetic diversity analysis and pedigree inferences for Florida cultivars using microsatellite markers. J. Amer. Soc. Hort. Sci. 131(2):214-224.

Schroeder, C.A. 1944. Multiple embryos in the avocado. J. Hered. 35:209-210.

Scora, R.W. and B. Bergh. 1990. The origins and taxonomy of avocado (Persea americana). Mill. Lauraceae. Acta Hort. 275:387-394.

Sedgley, M. 1977. Reduced pollen tube growth and the presence of callose in the pistil of the male floral stage of the avocado. Scientia Hort. 7:27-36.

Sedgley, M. and C.M. Annells. 1981. Flowering and fruit-set response to temperature in the avocado cultivar 'Hass'. Scientia Hort. 14:2733.

Sedgley, M. and W.J.R. Grant. 1983. Effect of low temperatures during flowering on floral cycle and pollen tube growth in nine avocado cultivars. Scientia Hort. 187:207-213.

Sedgley, M., P.B. Scholefield, and D.McE. Alexander. 1985. Inhibition of flowering of Mexican- and Guatemalan-type avocados under tropical conditions. Scientia Hort. 25:21-30.

Sharon, D., P.B. Cregan, S. Mhameed, K. Kusharska, J. Hillel, E. Lahav, and U. Lavi. 1997. An integrated genetic linkage map of avocado. Theor. Appl. Genet. 95:911-921.

Slate, J., T. Marshall, and J.M. Pemberton. 2000. A retrospective assessment of the accuracy of the paternity inference program Cervus. Mol. Ecol. 9:801-808.

Southeast Regional Climate Center. 2007. Homestead Exp. Stn., Fla., NCDC 1971-2000 monthly normals. 20 Nov. 2007. <http:// www.sercc.com/cgi-bin/sercc/cliMAIN.pl?fl4091>.

Stout, A.B. 1923. A study in cross-pollination of avocados in southern California. California Avocado Assn. Annu. Rpt. 1922-1923. 8:5792.

Stout, A.B. 1933. The pollination of avocados. Univ. of Florida Agr. Expt. Sta. Bull. 257.

Stout, A.B. and E.M. Savage. 1925. The flower behavior of avocados with special reference to interplanting. Proc. Florida Hort. Soc. 8089. Eustis, FL, April 7-9, 1925.

Sulaiman, Z., G. Collins, J. Witherspoon, and M. Sedgley. 2004. Identification of pollen donors for the avocado cultivar Gwen in a mixed orchard by isozyme analysis. J. Hort. Sci. Biotechnol. 79(4):571-575.

Torres, A.M. and B.O. Bergh. 1978. Isozymes as indicators of outcrossing among 'Pinkerton' seedlings. California Avocado Soc. Yrbk. 62:103-110.

Torres, A.M. and B.O. Bergh. 1980. Fruit and leaf isozymes as genetic markers in avocado. J. Amer. Soc. Hort. Sci. 105(4):614-619.

Torres, A.M., U. Diedenhofen, B.O. Bergh, and R.J. Knight. 1978. Enzyme polymorphisms as genetic markers in the avocado. Amer. J. Bot. 65(2):134-139.

University of Florida, Institute of Food and Agricultural Sciences, and Florida Automated Weather Network. 2007. Daily averages of temperature $\left({ }^{\circ} \mathrm{F}\right)$, rainfall (in), and relative humidity $(\%)$ measured at $2 \mathrm{~m}$ height for Homestead, Fla. from 1 Jan. 2006-1 May 2006. 19 Nov. 2007. <http://fawn.ifas.ufl.edu/data/reports/>.

Vrecenar-Gadus, M. and N.C. Ellstrand. 1985. The effect of planting design on out-crossing rate and yield in the 'Hass' avocado. Scientia Hort. 27:215-221.

Whiley, A.W. and D.G. Whiley. 2005. Rootstock improvement for the Australian avocado industry: A preliminary report. New Zealand and Australia Avocado Grower's Conference '05. Session 4. New germplasm and global breeding programmes. Tauranga, New Zealand. 20-22 Sept. 2005. 